\title{
Treatment of frontal bone fracture sequelae through inversion of the bone fragment
}

\section{Inversão do segmento fraturado para tratamento das sequelas de fratura do seio frontal}

Jonathan Ribeiro da Silva ${ }^{1,2}$; Carlos Fernando de Almeida Barros Mouräo²; Hernando Valentim da Rocha Júnior ${ }^{3}$; Luiz Fernando Magacho ${ }^{1}$; Guto Fidalgo Daumas Moraes ${ }^{1}$; Nicolas Homsi ${ }^{3}$.

\section{A B S T R A C T}

Treatment of frontal sinus fractures depends on the structures involved: the anterior wall, the posterior wall and the nasofrontal duct. It may vary from the correction of the defect in the anterior wall to the cranialization with obliteration of the nasofrontal duct. The inversion of the frontal sinus's anterior wall to correct the defect in the fractured region is a good treatment option for sequelae, since this technique eliminates or reduces the use of biomaterial in the area, and allows direct assessment of the permeability of the nasofrontal duct. This work describes the technique of fractured segment inversion for the treatment of frontal sinus fracture sequelae in a motorcycle accident victim.

Keywords: Frontal Bone. Fracture Fixation. Craniocerebral Trauma.

\section{INTRODUCTION}

$\mathrm{T}$ he frontal sinus is a pneumatized cavity internally lined with epithelium of the ciliated respiratory tract, located between the internal and external tables of the frontal bone, maintaining close relation with other sinuses of the face, orbit ceiling, and anterior cranial fossa'. The anatomical characteristics of the frontal bone render it resistant to fractures, requiring trauma with high energy dissipation to occur, as in cases of auto accidents, which account for $52 \%$ of frontal bone fractures ${ }^{1-4}$.

Frontal sinus fractures represent 2 to $15 \%$ of the maxillofacial trauma, and may be associated with other fractures of the middle third of the face, such as maxilla, zygomatic and naso-orbito-ethmoidal (NOE) ${ }^{1,5-7}$. Many classifications have been proposed in the literature to help manage such lesions, but most authors rely on the anatomical location of the fracture, involvement of the anterior wall, of the posterior wall and of the nasofrontal duct, either alone or in association ${ }^{2,8}$.

The treatment of frontal sinus fractures may range from a simple fixation of the anterior wall to a cranialization and obliteration of the nasofrontal duct, depending on anatomical location, bone comminution, degree of displacement, and presence of brain injury ${ }^{3,5,9,10}$. In cases where only the anterior wall is affected, the treatment varies from reduction and bone fixation, and correction with titanium meshes or with the use of biomaterials, $2,3,7,8,11$. In cases of sequelae of the anterior wall fractures, the inversion of the fractured segment becomes an interesting option to correct the local depression. The external face of the fractured anterior wall presents with a concavity, while its internal face becomes convex. Reversing this fractured segment through an osteotomy can correct the depression caused by the fracture, eliminating or reducing the use of biomaterials for aesthetic contour, and allowing the evaluation of the functionality of the nasofrontal duct by direct access after osteotomy.

The objective of this work is to demonstrate the technique of fractured segment inversion for the treatment of frontal sinus fractures sequelae.

\section{TECHNICAL NOTE}

A male patient, 20 years old, presented to the buccomaxillofacial surgery department of the Nova

1 - Nova Iguaçu General Hospital, Bucomaxilofacial Surgery Service, Rio de Janeiro, Rio de Janeiro State, Brazil. 2 - São José Faculties, Department of Buccomaxillofacial Surgery, Rio de Janeiro, Rio de Janeiro State, Brazil. 3 - Fluminense Federal University, Department of Buccomaxillofacial Surgery, Nova Friburgo, Rio de Janeiro State, Brazil. 


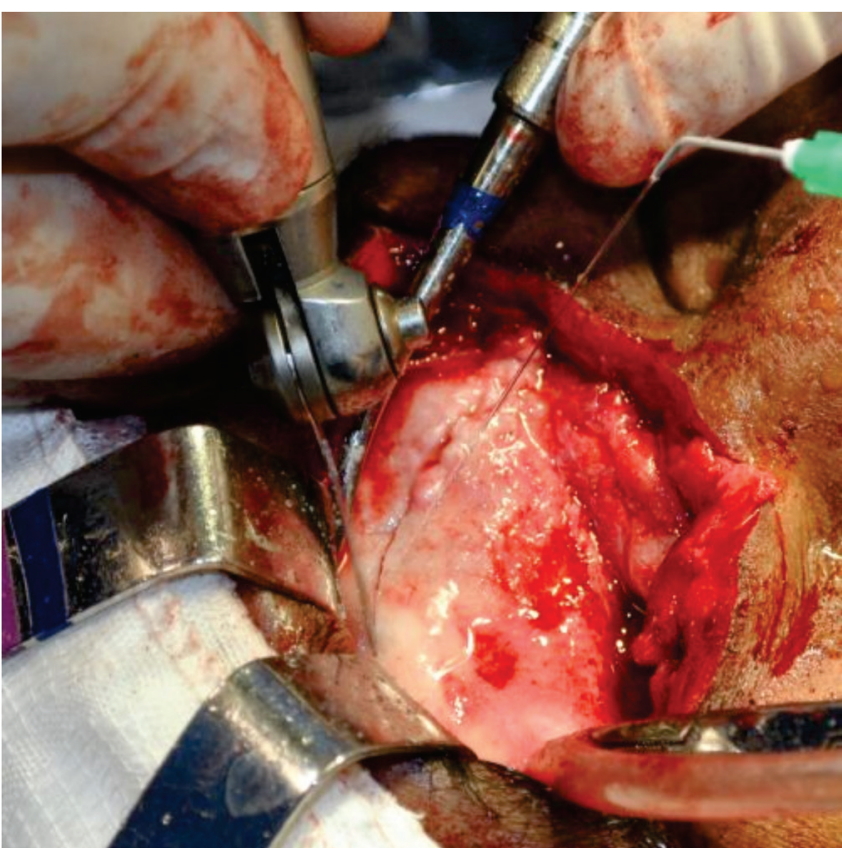

Figure 1 - Exposure of the fractured bone segment in the frontal region.

Iguaçu General Hospital (Nova Iguaçu, Rio de Janeiro, Brazil), with a depression in the frontal bone region that occurred after a traffic accident 44 days before the consultation, while he drove a motorcycle without a helmet. The tomographic evaluation showed a displaced fracture of the frontal sinus anterior wall and a fracture of its posterior wall.

After 60 days of trauma, the patient underwent a surgical procedure under general anesthesia.

Surgical access in these cases can be performed by a pre-existing scar or by coronal access. After dissection of the anatomical planes, the bone segment is identified and evaluated as for the presence of areas of comminuted and not yet consolidated bone (Figure 1). The areas of comminution may fracture during osteotomy, which increases the need of biomaterial for correction of the defect.

We use an oscillatory saw under heavy irrigation with $0.9 \%$ saline for osteotomy of the fractured segment in a single piece. With the aid of periosteal detachers, the segment is carefully removed, providing direct access to the frontal sinus so that the nasofrontal duct permeability test can be performed if indicated.

We then invert the fractured segment, perform the osteoplasty and reposition the fragment with its internal face facing the external environment,

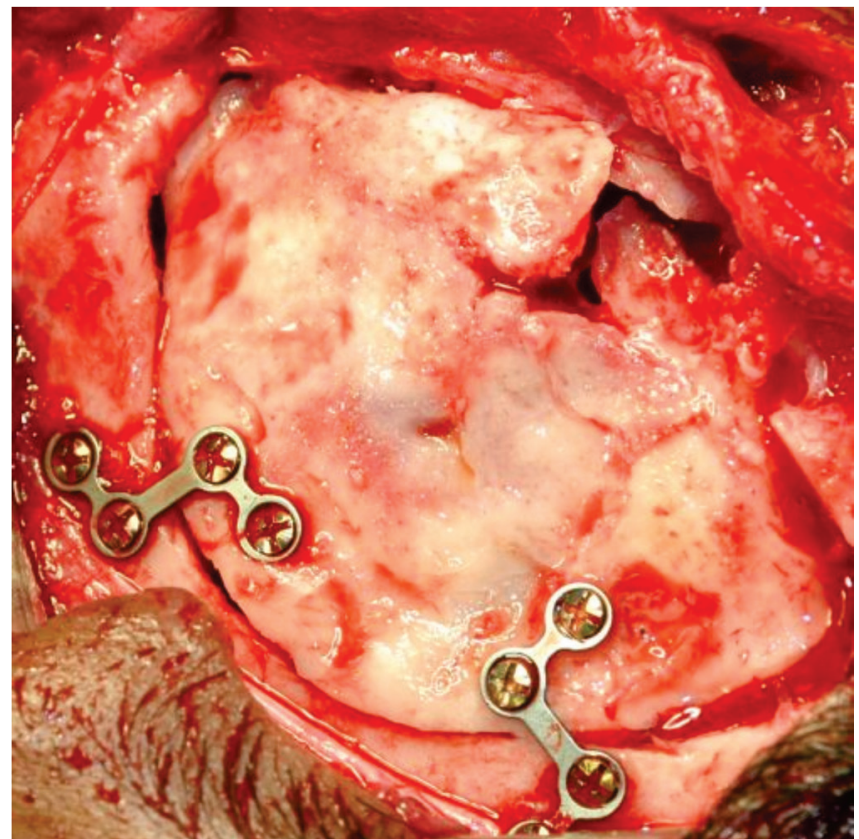

Figure 2 - Bone segment repositioned after inversion and osteoplasty.

providing the frontal sinus with its original anatomical shape and the availability to fix it with a system of 1.5$\mathrm{mm}$ or 1.2-mm miniplates (Figure 2).

After fixation of the segment, we evaluate the shape of the frontal bone, and if necessary, use some kind of biomaterial to improve the anatomy, as in cases of small fractures of comminuted and not yet consolidated areas. We perform single sutures on the frontal musculature and subcutaneous tissue with 3.0 absorbable sutures and on the skin with 5.0 nylon intradermal stitches.

In the immediate postoperative period, the patient usually presents local edema and may complain of mild to moderate pain in the operated area. After three months, the edema regresses and it is possible to notice the correction of the pre-existing depression. After five years of postoperative follow-up, the patient showed no signs of infection or any other complication related to the procedure. The aesthetic result was maintained in this period.

\section{DISCUSSION}

The treatment protocols for frontal sinus fractures are reported in the literature through classifications and organograms, where the majority of authors assess the degree of displacement and / 
or communication of the anterior and posterior walls, presence of intracranial lesions, and involvement or not of the nasofrontal duct 2,3,7-9.

When there is a dislocated and fragmented fracture of the posterior wall, the treatment of choice is cranialization, always associated with the obliteration of the nasofrontal duct, so that there is no communication of intracranial structures with the external environment ${ }^{9,11}$. Several techniques with different materials are described in the literature for this obliteration, such as abdominal fat, temporal fascia, pericranium, calcium phosphate, and hydroxyapatite'.

Anterior wall displaced fractures are usually treated with open reduction and fixation with miniplates, but other methods of treatment, such as the endoscopicallyassisted and the "camouflage" of the aesthetic defect, can also be used ${ }^{2,3}$. The main advantage of using the endoscope is the lower invasiveness, with conservative surgical access, resulting in better postoperative recovery, but with limited resolution of complex cases or sequelae $e^{9-11}$.
In sequelae case, the technique of camouflage with biomaterials and titanium meshes is the most used, since it allows the correction of the esthetic defect without the need of an osteotomy, with overlaying of only one material. The disadvantages of this technique are the cost increase and the difficulty in performing the nasofrontal duct patency test ${ }^{10}$. The technique we describe, of inversion of the frontal sinus's anterior wall, allows correction of the esthetic defect in cases of sequelae, reducing or eliminating the need of grafts. This method simplifies the technique of fixation and does not present a high level of complexity, besides providing a direct access to the frontal sinus, allowing the evaluation of the duct permeability.

We conclude that inversion of the fractured segment is a good treatment option for cases of frontal sinus anterior wall fracture. Although requiring longer surgical time, this procedure presents some advantages when compared with the traditional techniques of "camouflage" of the depression.

\title{
R E S U M O
}

\begin{abstract}
O tratamento das fraturas do seio frontal depende das estruturas envolvidas: a parede anterior, a parede posterior e o ducto nasofrontal. Os tratamentos podem variar entre corrigir um defeito na parede anterior até a realização de uma cranialização com obliteração do ducto nasofrontal. O uso da inversão da parede anterior do seio frontal para corrigir o defeito na região fraturada representa uma boa opção de tratamento para os casos de sequelas, já que esta técnica elimina ou reduz a utilização de biomaterial nesta área, e permite avaliação da permeabilidade do ducto nasofrontal por acesso direto. Este trabalho descreve a técnica de inversão do segmento fraturado para tratamento de sequelas de fratura do seio frontal em paciente vítima de acidente motociclístico.
\end{abstract}

Descritores: Osso Frontal. Fixação de Fratura. Traumatismos Craniocerebrais.

\section{REFERENCES}

1. Manolidis S. Frontal sinus injuries: associated injuries and surgical management of 93 patients. J Oral Maxillofac Surg. 2004;62(7):882-91.

2. Bell RB. Management of frontal sinus fractures. Oral Maxillofac Surg Clin North Am. 2009;21(2):227-42.

3. Bell RB, Dierks EJ, Brar P, Potter JK, Potter BE. A protocol for the management of frontal sinus fractures emphasizing sinus preservation. J Oral Maxillofac Surg. 2007;65(5):825-39.

4. El Khatib K, Danino A, Malka G. The frontal sinus: a culprit or a victim? A review of 40 cases. J Craniomaxillofac Surg. 2004;32(5):314-7.

5. Gerbino G, Roccia F, Benech A, Caldarelli C. Anal- ysis of 158 frontal sinus fractures: current surgical management and complications. J Craniomaxillofac Surg. 2000;28(3):133-9.

6. Stanwix MG, Nam AJ, Manson PN, Mirvis S, Rodriguez ED. Critical computed tomographic diagnostic criteria for frontal sinus fractures. J Oral Maxillofac Surg. 2010;68(11):2714-22.

7. Strong EB, Pahlavan N, Saito D. Frontal sinus fractures: a 28-year retrospective review. Otolaryngol Head Neck Surg. 2006;135(5):774-9.

8. Tiwari P, Higuera S, Thornton J, Hollier LH. The management of frontal sinus fractures. J Oral Maxillofac Surg. 2005;63(9):1354-60.

9. Rodriguez ED, Stanwix MG, Nam AJ, St Hilaire $H$, Simmons OP, Christy MR, et al. Twenty-six-year ex- 
perience treating frontal sinus fractures: a novel algorithm based on anatomical fracture pattern and failure of conventional techniques. Plast Reconstr Surg. 2008;122(6):1850-66.

10. Fattahi T, Johnson C, Steinberg B. Comparison of 2 preferred methods used for frontal sinus obliteration. J Oral Maxillofac Surg. 2005;63(4):487-91.

11. Montovani JC, Nogueira EA, Ferreira FD, Lima Neto AC, Nakajima V. Cirurgia das fraturas do seio frontal: estudo epidemiológico e análise de técnicas. Rev Bras Otorrinolaringol. 2006;72(2):204-9.
Received in: 11/08/2016

Accepted for publication: 29/09/2016

Conflict of interest: none.

Source of funding: none.

\section{Mailing address:}

Carlos Fernando de Almeida Barros Mourão

E-mail: mouraoufrj@yahoo.com.br carlosmourao@saojose.br 